\title{
Wbrew humanizmowi. Racjonalizm transcendentalny Bogusława Wolniewicza
}

Recenzja:

\author{
Bogusław Wolniewicz, Filozofia i wartości $I V$, Wydawnictwo Uniwersytetu \\ Warszawskiego, Warszawa 2017, s. 329.
}

\section{Stanisław Jędrczak}

Pierwszy tom Filozofii i wartości, zbiór rozpraw z antropologii filozoficznej i aksjologii formalnej, ukazał się w 1991 roku, ćwierć wieku temu. W poprzedzającym go Wstępie Profesor Bogusław Wolniewicz napisał: „Zebrane tu rozprawy i wypowiedzi łączy nie tylko osoba ich autora i luźna wspólnota tematyki zaznaczona w tytule. Reprezentują one także - i chyba dość jednolicie - pewien sposób uprawiania filozofii, odmienny od obu dziś panujących: pozytywistycznego i hermeneutycznego"1. „Ostatni to już zbiór przemyśleń, jakie udało mi się doprowadzić do końca. Razem wyrażają pewne stanowisko filozoficzne, do którego autor dochodził przez lata. Można je określić jako transcendentalny racjonalizm” (s. 7) - czytamy w wydanym jesienią ubiegłego roku tomie czwartym. Zawarte w nim rozprawy, pisane w latach 1991-2014, dają obraz stanowiska filozoficznego kształtowanego na przestrzeni półwiecza, systemu filozoficznego, którego rdzeniem jest ontologia sytuacji.

STANISŁAW JĘDRCZAK, Kolegium Międzyobszarowych Indywidualnych Studiów Humanistycznych i Społecznych, Uniwersytet Warszawski; adres do korespondencji, Kolegium Międzyobszarowych Indywidualnych Studiów Humanistycznych i Społecznych UW, ul. Dobra 72, 00-001 Warszawa; e-mail: s.jedrczak@student.uw.edu.pl

${ }^{1}$ B. Wolniewicz, Filozofia i wartości, Wydawnictwo UW, Warszawa 1991, s. VII. 
Rysem filozofii racjonalnej jest przekonanie, że „nerwem filozofii jest logika”, a „we wszelkiej filozofii jest tyle nauki, ile jest w niej logiki”2. Rysem filozofii transcendentalnej zaś - antropologia, która głosi, że „człowiek nie jest tylko częścią przyrody, lecz wykracza poza nią"”. Jest to logiczna filozofia ducha. Racjonalizmowi transcendentalnemu, nazywanemu także tychicznym, przeciwstawia Wolniewicz „dziejowe fluktuacje ducha” (s. 54): z jednej strony naturalizm irracjonalny, czyli postmodernizm, a z drugiej - racjonalizm naturalistyczny, czyli pozytywizm.

Własne stanowisko filozoficzne Wolniewicz sytuuje w opozycji do pozytywizmu, reprezentowanego w szkole warszawskiej; w szczególności przez Tadeusza Kotarbińskiego - „symbol wielkości polskiej filozofii w XX wieku i jej usilnego dążenia do pojęciowego ładu”. „Tendencja jasnościowa”, a zarazem styl literacki Kotarbińskiego, stanowią wzorzec stylu Wolniewicza. Inne źródło filozoficzne stanowi aksjologia Henryka Elzenberga; Kotarbiński i Elzenberg, zdaniem Wolniewicza, tworzą spectrum polskiej filozofii XX wieku. „Wraz z paru kolegami tworzymy w polskiej filozofii pewien kierunek, bardzo źle widziany, który nazwałbym Elzenbergizmem" powiada Wolniewicz (s. 54), wymieniając wśród swoich mistrzów m.in. Tadeusza Czeżowskiego, założyciela szkoły toruńsko-wileńskiej, Elzenberga i Romana Suszkę. We Wstępie do pierwszego tomu Filozofii i wartości wspomina także Adama Schaffa: „Głęboko zobowiązany czuję się też wobec Adama Schaffa, za którego sprawą znalazłem się w 1963 r. na Uniwersytecie Warszawskim”" . Te słowa zostały powtórzone w tomie czwartym: „chcę ponownie wyrazić swoją wdzięczność dla pamięci profesora Schaffa. Nie uświadamiałem sobie ongiś jak dziś, że sprowadzenie mnie przez niego do Warszawy stanowiło w moim życiu naukowym punkt zwrotny" (s. 10).

Filozofię Wolniewicza odróżnia od szkoły warszawskiej „skłonność metafizyczna”. „W szkole warszawskiej raziło mnie jej sekciarstwo - pozytywistyczne” (s. 57). Różnicę tę rysuje uwaga odnotowana we wspomnieniu o Marianie Przełęckim: „Filozoficznie staliśmy na antypodach: on przy Kotarbińskim i Carnapie, ja przy Elzenbergu i Wittgensteinie" (s. 228).

\footnotetext{
${ }^{2}$ Tamże, s. IX.

3 Tamże, s. 96.

4 Tamże, s. IX.
} 
Książka dzieli się na cztery części. W odróżnieniu od poprzednich tomów nie zawiera wypowiedzi - fragmentów filozofii praktycznej utrzymanych w publicystycznym tonie. Część pierwsza składa się z rozpraw logiczno-metafizycznych. Skupiają się one wokół zasadniczych „opozycji” metafizyki Wittgensteina: sensu i znaczenia, zdania i sytuacji, sytuacji i przedmiotu; ostatnia rozprawa, inspirowana rozważaniami Petera Geacha, to wyobrażenie „logiki Bożej” (obecność Geacha w książce wydaje się warta podkreślenia, zważywszy na jej apologetyczną wymowę). Część druga, logiczno-antropologiczna, poświęcona została problemowi hedonizmu oraz niektórym wątkom filozofii praktycznej Kanta (w perspektywie dyskursywnej, nie historycznej); zawiera także rozprawę krytyczną o miejscu sądownictwa w demokracji liberalnej.

Oprócz osobistych wspomnień (dedykowanych Przełęckiemu i Geachowi), a także wyjątków z wydanej w roku 2011 książki O Polsce i życiu, w czwartym tomie Filozofii i wartości znajduje się esej $O$ chrześcijaństwie ${ }^{5}$. Esej ten, nawiązujący do klasycznej pracy $O$ istocie religii, przedstawia stanowisko Wolniewicza wobec chrześcijaństwa; można by nazwać je dialektycznym. Łączy ono bowiem religijną cześć z brakiem wiary, posłuszeństwo ze sceptycyzmem, choć nie pozbawionym nadziei, wobec perspektyw chrześcijaństwa. Stanowisko to, choć autonomiczne i niekonfesyjne, jest jednocześnie apologetyczne, nawiązując tym do Pascala. O rozprawie tej powiedzmy kilka słów więcej.

Filozoficzne zainteresowanie chrześcijaństwem ma motywacje Heglowskie. Zdaniem Wolniewicza, „ławę” cywilizacji Zachodu stanowią nauka i chrześcijaństwo. Kryzys chrześcijaństwa jest więc kryzysem cywilizacji Zachodu, jego zaczynem lub echem. Namysł nad chrześcijaństwem jest zaś wyrazem samowiedzy epoki. Wolniewicz podziela profetyczne przekonanie Miłosza: „Miłosz powiedział Brodskiemu: Cywilizacja Zachodu wkracza obecnie w pełnię nihilizmu. Przemianę tę widać dzisiaj gołym okiem, a jej zawołaniem jest humanizm. Przeszkodą

${ }^{5}$ Zob. O chrześcijaństwie, [w:] Księga pamiątkowa Marianowi Przełęckiemu w darze na 90-lecie urodzin, red. A. Brożek, J. J. Jadacki, Norbertinum, Lublin 2014. 
jest mu chrześcijaństwo" (s. 203). Podczas odczytu na Uniwersytecie Warszawskim, wygłoszonego w grudniu ubiegłego roku', Wolniewicz przytoczył wypowiedź Benedykta XVI (także urodzonego w 1927 roku). Pytany o przyszłość chrześcijaństwa, Benedykt XVI odpowiedział: „Nie przystajemy do współczesnej kultury. Dlatego społeczeństwo zachodnie nie będzie po prostu chrześcijańskie”. Przyczyną nieprzystawania jest zdaniem Wolniewicza rozdźwięk chrześcijaństwa i nowoczesnej nauki. Przyszłość chrześcijaństwa - przeciwstawianego nihilizmowi - zależeć ma od spójności naukowego i chrześcijańskiego obrazu świata. Diagnoza ta jest zarazem zadaniem dla filozofii współczesnej. Filozofia powinna bowiem dążyć do owego uspójnienia; nauka, można rzec za Pascalem, oddala się od człowieka, stwarzając - słowa Wolniewicza - obraz świata jedynie „przypadkowego i wypranego z sensu”. Religia zaś, której zasadą jest posłuszeństwo, nie znajduje porozumienia $\mathrm{z}$ pooświeceniowym racjonalizmem. Pomostem między racjonalizmem nauki a chrześcijańską eschatologią ma stać się filozofia; rolę filozofii współczesnej widzi więc Wolniewicz podobnie, jak widział ją w połowie XVII wieku Pascal.

Wobec tego zadania filozofia naturalistyczna pozostaje bezsilna, powiada Wolniewicz, przywołując uwagę Pascala o naturalistach: „Czyż myślą, że nas tak znów ucieszyli, mówiąc nam, że nasze dusze to tylko odrobina wiatru i dymu?” (s. 300). Naturalizm bowiem, odrzucając ludzką transcendencję ponad świat przyrody, przyznaje, że nauka wyczerpuje wiedzę o rzeczywistości. Istota zjawisk jest empiryczna, a zgłębia ją nauka. Tę funkcję heurystyczną może jednak spełnić racjonalizm transcendentalny.

Wolniewicz twierdzi za Heglem: „Religia zaczyna się ze świadomością, że jest coś wyższego niż człowiek” (s. 205). Jednocześnie korzeniem religii — warunkiem koniecznym najbliższym — jest śmierć. „W zderzeniu woli życia z wiedzą śmierci rodzi się poruszenie duszy, które Constant nazywa „czuciem religijnym”. Dusza tak poruszona szuka równowagi swojej woli z ową wiedzą, a także stosownych form jej wyrazu, przez które ten wstrząs mógłby znaleźć sobie ujście. Świadomość,

${ }^{6}$ Wykład odbył się 5 grudnia 2016 r. podczas seminarium prowadzonego przez dr. hab. Pawła Okołowskiego. Był to pierwszy wykład wygłoszony przez prof. Wolniewicza na Uniwersytecie Warszawskim w cyklu akademickim od 17 lat.

${ }^{7}$ Benedykt XVI, Ostatnie rozmowy, tłum. J. Jurczyński, Wydawnictwo RAFAEL, Warszawa 2016, s. 269. 
na którą wskazał Hegel, znaczy, że je znalazła” (s. 205). „Religia jest najbardziej adekwatnym stosunkiem człowieka do śmierci, na jaki ludzkość potrafiła się zdobyć", ",Religia jest to zorganizowana wspólnota duchowa w obliczu śmierci”.

Filozofia śmierci, formułowana przez Wolniewicza wywodzi się z Traktatu Wittgensteina. Myślenie o śmierci Wittgensteina stoi w jaskrawej opozycji do późniejszego egzystencjalizmu. Między innymi Camus i Sartre poddawali w wątpliwość sens życia, skoro kończy się ono śmiercią. Przeciwnie Wittgenstein. Uważał on, że życie zyskuje sens dzięki śmierci. Śmierć, granica życia, jest zarazem warunkiem jego sensowności; wobec śmierci życie może być słuszne, posługując się pojęciem Elzenberga. Jak zdanie jest sensowne dzięki logice - granicy sensownego wyrazu myśli, tak życie - dzięki śmierci. Wolniewicz powiada również: „Śmierć pełni wobec życia funkcję konsekracyjną, uświecającą" ${ }^{\prime \prime}$. Przytoczmy fragment jego polemiki z Kołakowskim. „Kołakowski pisze: „Religia jest sposobem, w jaki człowiek akceptuje swoje życie jako nieuchronną porażkę. Że nie jest ono nieuchronną porażką, można wierzyć tylko mala fide. Czemu tylko „mala fide”, w złej wierze? W każdym razie to nie po chrześcijańsku, niezależnie od wiary w zmartwychwstanie. Apostoł, czekając na rychłe stracenie, tak podsumował swoje życie (II Tym 4,7): «Bojowałem dobrym bojowaniem, do mety dobiegłem, wiarę zachowałem»". Więcej nie trzeba: starczy dobiec, czyli zrobić, co w życiu naszym było do zrobienia. Nie każdy dobiega, więc życie może być porażką, ale nie musi. Zestawiając Hegla z Nietzschem, widzimy, że religia to przeciwny biegun do nihilizmu. Kołakowski był sceptyk, a od sceptycyzmu do nihilizmu tylko krok. W przytoczonej tezie krok ten uczynił: na nic nasze bojowanie, skoro życie ma kres" (s. 206).

Nihilizm jest to podporządkowanie wartości wyższych wartościom utylitarnym, „którymi są własne życie i własne użycie. (U Seneki esse et bene esse, u Schopenhauera Dasein und Wohlsein)" (s. 205). Jednym z wyrazów nihilizmu jest antropocentryczny humanizm nihilistyczny, który Wolniewicz odróżnia od humanizmu aksjocentrycznego. „W obu przypadkach wartością naczelną jest «człowiek», różnie jednak pojmowany: raz materialnie jako «życie ludzkie», raz idealnie

\footnotetext{
${ }^{8}$ B. Wolniewicz, O istocie religii, [w:] Filozofia i wartości, dz. cyt., s. 176.

${ }^{9}$ Tamże, s. 179.

${ }^{10}$ Tamże, s. 173.
} 
jako «człowieczeństwo» (s. 203). Tak pojmowany humanizm nihilistyczny jest absolutyzacją ludzkiego „pędu, by trwać wciąż dalej i dalej: in suo esse perseverarum, jak mówi Spinoza” (s. 206), kultem życia. Niemym wsparciem dla niego jest technika, zwłaszcza biotechnologia: narzędzie, które toruje nauce drogę do ludzkiego życia. Zachodnia „nauka dotyka samych naszych pojęć o tym, co dobre i złe”11. Peter Hacker zauważył, że wielu z nas mężczyźni w białych kitlach mają więcej czaru niż Bóg ${ }^{12}$.

Spór chrześcijaństwa z nihilistycznym humanizmem toczy się o wartość życia. „Widoki chrześcijaństwa zależą od tego, na ile trafnie Kościół odczytuje znaki czasu"13. Korzeniem religii jest śmierć. Zmiana stosunku do śmierci jest wyrazem religijności, zdaniem Wolniewicza nihilizmu, przejawiającej się w laickim humanizmie. W cywilizacji nihilistycznej - której credo streszcza słowami Seneki ostatnim absolutem jest życie, a jego wyrazem scjentystyczne iluzje życia bezkresnego (czego jaskrawy przykład stanowi krionika). Jednakże, powiada Pascal, „Wiedza rzeczy zewnętrznych nie opłaci mi się w chwilach zgryzoty moralnej”"14.

Chrześcijaństwo, wbrew humanizmowi, znamionuje zaś realistyczny stosunek do śmierci: „nic nie jest bardziej przeciwne duchowi chrześcijaństwa niż chęć, by z przedłużania życia doczesnego czynić dobro absolutne lub choćby tylko dobro bardzo wysokie"15. W O istocie religii Wolniewicz przywołał słowa Ratzingera pochodzące z klasycznej książki Śmierć i życie wieczne: „Specyfiką chrześcijaństwa jest przekonanie o wielkości człowieka i powagą ludzkiego życia: są w tym życiu sprawy nieodwołalne i jest nieodwołalne zniszczenie. Taka jest rzeczywistość i chrześcijanin musi być świadomy tej rzeczywistości”16.

Stosunek Wolniewicza do chrześcijaństwa jest dialektyczny; chrześcijańskiemu realizmowi przeciwstawia on irrealistyczną etykę śmierci. „Odróżnijmy etykę abstrakcyjną i konkretną; to, co ludzie głoszą, od tego, co czynią. Między

${ }^{11}$ B. Wolniewicz, O tzw. bioetyce, [w:] Filozofia i wartości III, Wydawnictwp UW, Warszawa 2003, s. 149.

${ }^{12}$ P. Hacker, Human Nature. The Categorial Framework, Blackwell 2007, s. 305.

${ }^{13}$ B. Wolniewicz, Perspektywy eutanazji, [w:] Filozofia i wartości III, dz. cyt., s. 174.

${ }^{14}$ B. Pascal, Myśl, tłum. T. Boy-Żeleński, Hachette, Warszawa 2008, s. 196.

${ }^{15}$ B. Wolniewicz, Filozofia i wartości III, dz. cyt., s. 174.

${ }^{16}$ J. Ratzinger, Śmierć i życie wieczne, cyt. za: B. Wolniewicz, Filozofia i wartości, dz. cyt., s. 171. 
tymi dwoma poziomami etyki jest zawsze rozstęp... Od rozstępu poziomów zależy realność etyki. Gdy rozstęp jest mały, etyka jest realna; gdy wielki - irrealna" (s. 220). Wolniewicz, jak Kotarbiński i Elzenberg, pozostaje krytyczny wobec stosunku Kościoła do eutanazji, a więc postawy wobec umierających, czyli formy religijnej współczesnego chrześcijaństwa. Przed laty Wolniewicz napisał: „Śmierć zawsze za rychła - jest nieodłączna od kondycji ludzkiej... Odrzuca się tutaj scjentystyczne mrzonki i próbuje zachować wobec własnej śmiertelności zimną krew i techniczną rzeczowość... Skoro od śmierci nie ma dla nas ucieczki, to trzeba zrobić wielki zwrot i wyjść jej naprzeciw: odjąć jej grozę umierania w bezsensownej męce"17. Punkt sporu z chrześcijaństwem wytyczył zaś wyraźnie. Był nim stosunek do niezawinionego cierpienia, jakie towarzyszy śmierci. Wyrównać krzywdę na ziemi to położyć jej kres. Znaczy to niekiedy: pozbawić życia. Życie zbiega nieuchronnie do śmierci. Ponieważ „Niebo jest puste”, umieranie w cierpieniu nie służy niczemu. „Religia, która tak widzi świat, musi być w swojej etyce bardziej surową i przynaglającą do czynu, niż ta, co w swym obrazie świata rysuje widoki pośmiertnych wyrównań. Tu ich nie ma, niczego nie można odkładać na potem. Życie ludzkie nie jest... drogą do zbawienia, tylko zagadkowym dramatem - tym bardziej niepojętym, im zwyczajniej przedstawia się postronnym"19.

W rozprawie $O$ chrześcijaństwie postawę Wolniewicza wobec chrześcijaństwa można określić mianem sojuszniczej. Czytamy: „Prawdziwym źródłem sprzeciwu wobec eutanazji nie jest wiara chrześcijańska... Źródło leży gdzie indziej: w duszach tli się głuchy opór przed tak bliskim i praktycznym wglądaniem w otchłań własnej śmierci” (s. 214). Dawny stoicki fatalizm ustąpił chrześcijaństwu sui generis. Ton Wolniewicza brzmi apologetycznie: „Etyka ewangeliczna to nie irrealizm. Nie żąda od ludzi więcej, niż mogą, nie wzywa do samozatraty ani innych wyczynów moralnych. Jest przyziemna i szara” (s. 222). Apologetyczny wydźwięk rozprawy $O$ chrześcijaństwie uwydatniają uwagi o Jezusie, „postaci wzniosłej i tajemniczej”20, nieprzeniknionej (s. 208).

\footnotetext{
${ }^{17}$ B. Wolniewicz, Filozofia i wartości III, dz. cyt., s. 187.

${ }^{18}$ Tamże, s. 174.

${ }^{19}$ Tamże, s. 175.

${ }^{20}$ Tamże, s. 208.
} 
Łącznie z rozprawą $O$ chrześcijaństwie tom liczy dwadzieścia jeden artykułów filozoficznych. Wszystkie publikowane były wcześniej (należy wymienić m.in. odczyty $O$ sensie i znaczeniu $z d a n^{21}$, $O$ zdaniach syntetycznych a priori ${ }^{22}$ oraz esej zatytułowany Hedonizm i obowiązek). Książka daje obraz stylu filozoficznego Profesora Wolniewicza, wysłowionego przez Wittgensteina: „cokolwiek da się powiedzieć, da się jasno powiedzieć”23. Brak w niej nowinkarstwa; przeważa wytężony namysł nad myślą Kanta i Wittgensteina. W pisarstwie Wolniewicza Wittgenstein prowadzi spór z klasykami. Spośród filozofów polskich szczególnie eksponowani są Kotarbiński, Elzenberg, Czeżowski i Suszko oraz przedstawiciele filozofii nieakademickiej: Miłosz i Lem.

Filozofia Wolniewicza nie jest autotematyczna („Do wszelkiej metafilozofii mam stosunek negatywny. Gdy filozofia nie ma nic do powiedzenia o rzeczywistości, zaczyna zajmować się sama sobą", s. 205) ani historyczna, lecz dyskursywna - rozstrzyga problemy filozoficzne. Stanowi wyzwanie dla myślenia hedonicznego, wspartego na nowoczesnej technice. Myślenie hedoniczne jest wszakże wyrazem „metafizycznej skazy świata”, którą Wolniewicz widzi w grzechu. Filozofia kultury, zakorzeniona w problemach nowoczesności z jej miłością postępu, splata się więc z chrześcijańską antropologią grzechu.

Choć nazwisko Pascala wspomina Wolniewicz zaledwie jednokrotnie, czwarty tom Filozofii i wartości ma wymowę jawnie Pascalowską. Jak filozofia Pascala, tak racjonalizm transcendentalny - wolny od konfesyjności - wydaje się tyleż wykładem filozofii, ile filozoficznym wyzwaniem (choć nie interpretacyjnym, a problemowym). Filozofia merytoryczna, wsparta na logice, jest jednocześnie głosem krytycznym wobec filozofii uprawianej współcześnie - zdaniem Wolniewicza wyjałowionej z idei (styl filozoficzny Wolniewicza zastępuje wszelką metafilozofię). Kończąc, powiemy więc za Pascalem: „Nie jest w naturze człowieka

${ }^{21}$ J. Golińska-Pilarek, A. Wójtowicz (red.), Identyczność znaku czy znak identyczności? Księga jubileuszowa dedykowana Profesorowi Mieczysławowi Omyle z okazji siedemdziesiątej rocznicy urodzin, Wydawnictwo UW, Warszawa 2012.

${ }^{22}$ Szkice z semantyki i ontologii sytuacji, red. M. Omyła, Polskie Towarzystwo Semiotyczne, Warszawa 1991.

${ }^{23}$ L. Wittgenstein, Traktat logiczno-filozoficzny, tłum. B. Wolniewicz, PWN, Warszawa 2007, t. 4.166. Wittgenstein mawiał: człowieka można poznać już tylko po jednym zdaniu. 
iść ciągle naprzód, ma ona swoje przypływy i odpływy. Gorączka ma swoje dreszcze i swoje żary; zimno wskazuje równie dobrze siłę gorączki jak samo gorąco"24.

\section{Bibliografia}

Benedykt XVI, Ostatnie rozmowy, tłum. J. Jurczyński, Wydawnictwo RAFAEL, Warszawa 2016.

Hacker P., Human Nature. The Categorial Framework, Blackwell 2007.

Identyczność znaku czy znak identyczności? Księga jubileuszowa dedykowana Profesorowi Mieczysławowi Omyle z okazji siedemdziesiątej rocznicy urodzin, red. J. Golińska-Pilarek A. Wójtowicz, Wydawnictwo UW, Warszawa 2012. Księga pamiątkowa Marianowi Przełęckiemu w darze na 90-lecie urodzin, red. A. Brożek, J. J. Jadacki, Norbertinum, Lublin 2014.Pascal B., Myśli, tłum. T. Boy-Żeleński, Hachette, Warszawa 2008.

Putnam H., Pragmatyzm. Pytania otwarte, tłum. B. Chwedeńczuk, Fundacja Aletheia, Warszawa 1999.

Ratzinger J., Śmierć i życie wieczne, tłum. M. Węcławski, IW PAX, Warszawa 1986.

Szkice z semantyki i ontologii sytuacji, red. M. Omyła, Polskie Towarzystwo Semiotyczne, Warszawa 1991.

Wittgenstein L., Traktat logiczno-filozoficzny, tłum. B. Wolniewicz, PWN, Warszawa 2007.

Wolniewicz B., Filozofia i wartości, Wydawnictwo UW, Warszawa 1991.

Wolniewicz B., Filozofia i wartości, t. III, Wydawnictwo UW, Warszawa 2003.

Information about Author:

STANISŁAW JĘDRCZAK, Kolegium Międzyobszarowych Indywidualnych Studiów Humanistycznych i Społecznych UW; address for correspondence: Kolegium Międzyobszarowych Indywidualnych Studiów Humanistycznych i Społecznych UW, ul. Dobra 72, PL 00-001 Warszawa; e-mail: s.jedrczak@student.uw.edu.pl

\section{(c)) EY-NG-ND}

${ }^{24}$ B. Pascal, Myśl, tłum. T. Boy-Żeleński, Warszawa 2008, s. 186. 